\title{
Sustainable Management of Algae in Eutrophic Ecosystems
}

\author{
William W. McNeary ${ }^{1}$, Larry E. Erickson ${ }^{2}$ \\ ${ }^{1}$ Department of Chemical Engineering, University of Missouri-Columbia, Columbia, USA; ${ }^{2}$ Department of Chemical Engineering, \\ Kansas State University, Manhattan, USA. \\ Email:wwmbq6@mail.missouri.edu, lerick@ksu.edu
}

Received July 23 ${ }^{\text {rd }}, 2013$; revised August $25^{\text {th }}, 2013$; accepted September $22^{\text {nd }}, 2013$

Copyright (C) 2013 William W. McNeary, Larry E. Erickson. This is an open access article distributed under the Creative Commons Attribution License, which permits unrestricted use, distribution, and reproduction in any medium, provided the original work is properly cited.

\begin{abstract}
The accelerated eutrophication of the world's freshwater and marine ecosystems is a complex problem that results in decreased productivity, loss of biodiversity, and various economic woes. Controlling algae populations in a eutrophic water body has values in mitigating some of these negative effects. This paper reviews a number of strategies for algae management, with a focus on sustainable practices that have minimal environmental impact. The information in the literature is then used to propose a design for an integrated algae-aquaculture system to be used for the dual purposes of nutrient assimilation and production of fish and algal biomass. Effectiveness of the proposed system and possible revenue streams to offset capital costs are examined; other solutions that utilize the techniques in the literature are also explored.
\end{abstract}

Keywords: Algae; Nutrients; Eutrophication; Ecosystem; Dead Zone

\section{Introduction}

Anthropogenic eutrophication of the world's aquatic ecosystems, both marine and freshwater, is a serious environmental, social, and economic concern. As human society advances, many of the agricultural and industrial processes necessary to maintain our quality of life inadvertently release nutrients (primarily nitrogen and phosphorus) into nearby waterways. Increased nutrient loading into lakes, reservoirs, and coastal areas promotes sudden biomass growth, which inevitably results in large amounts of dead plant and animal matter in the water; the aerobic bacteria that consume the detritus create a lowoxygen (hypoxic) environment that damages other aquatic life and can disrupt delicate ecosystems [1]. Algae and cyanobacteria blooms resulting from the eutrophication process often compound the problem by causing taste and odor problems and producing harmful toxins that can endanger the health of those who utilize the water body for recreation or drinking water [2]. In the Gulf of Mexico, where stratification between the incoming freshwater and the saline Gulf water exacerbates oxygen deficiency, the "Dead Zone" that appears annually averages over 5000 square miles every year, and is severely detrimental to both the tourism and fishing industries - the NOAA estimates losses for both to be on the order of $\$ 82$ million per year [3]. Freshwater eutrophication in the United States results in value losses in recreational water usage, waterfront real estate, threatened/endangered species recovery, and drinking water, all of which incur annual costs of nearly $\$ 2.2$ billion [4]. Obviously, effective and sustainable solutions are required to address a problem of this magnitude.

A key to any eutrophication management strategy is the control of the nutrient sources affecting the water body. Point sources, such as industrial effluents, and nonpoint sources, like agricultural fields, require different methods of control. Point source nutrient output is commonly influenced by governmental policies, such as phosphate bans or discharge limits; non-point sources require collaboration between landowners and governing bodies across watersheds to implement best management practices for fertilizer application and erosion control [2]. In order to increase the effectiveness of these tactics and minimize recovery time, other mitigation strategies in and around the eutrophic water body are often used in tandem with source reduction. 
This paper will conduct a review of established mitigation technologies, as well as newly-developed methods that hold promise in combating eutrophication. All strategies discussed will have greatest utility when used as a supplement to source reduction; on their own, their effects may be marginal. In addition, a brief overview of integrated algae-aquaculture systems will be conducted, followed by a proposal for a sustainable aquaculture system in the Mississippi delta that is meant to address the Gulf of Mexico dead zone and produce marketable products.

\section{Mitigation Strategies}

\subsection{Biomanipulation}

The effects of increased nutrient loading are felt throughout the ecosystem of a body of water experiencing eutrophication. The trophic cascade model (see Figure 1) is often used to visualize the relationships between organisms involved in the pelagic food web, which is the first system affected by nutrient influx. It is widely understood that phytoplankton populations explode when limiting nutrients are delivered in excess; fish biomass also increases with them. However, zooplanktivorous fish species often come to dominate in the new nutrient rich environment [5], which results in a "top down" effect on the food web in which the diminished zooplankton population is no longer able to hold the booming phytoplankton in check, thereby worsening the algae bloom issues.

Ecosystem restructuring that utilizes the trophic cascade model as a tool to increase water quality and decrease phytoplankton population is known as biomanipulation [6]. Typically, biomanipulation schemes involve restructuring the eutrophic food web by supplementing the population of piscivorous fish in order to control zooplanktivorous fish and alleviate pressure on the algaegrazing zooplankton populations [6,7]. Addition of filter-feeding fish such as tilapia has also been attempted in hopes to directly control the algae population [8]. Biomanipulation is an attractive option for combating the effects of cultural eutrophication due to its comparatively low implementation costs and utilization of existing natural systems, but potential drawbacks do exist. Strategies proven successful in temperate climate water bodies do not always find the same level of success when implemented in tropical environments - indeed, some instances of further water quality degradation due to invasive species and nutrient excretion levels of certain fish species have been recorded [5,7,8]. It is hypothesized that unintended consequences such as these result from the more diverse trophic structure of tropical water bodies. The long-term effectiveness of biomanipulation also remains in doubt; therefore, it is recommended that all such strategies be evaluated on a case-by-case basis and undertaken only by parties with a firm working knowl-

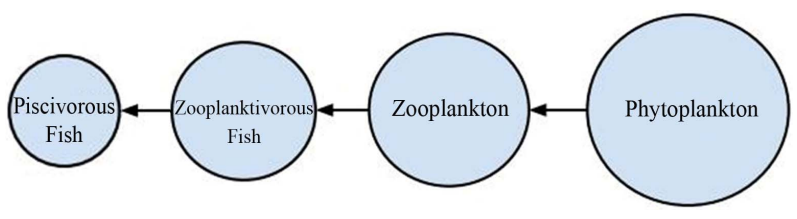

Figure 1. Trophic cascade model (adapted from [6]).

edge of the food webs at work in the ecosystem of the water body in question [6].

\subsection{Artificial Circulation}

Artificially-induced mixing of hypoxic water bodies holds value in eutrophication control. Typical circulation techniques can be broken down into two categories: destratification, in which water or air is forced into the bottom of the water column, thereby encouraging mixing and destroying the temperature gradient, and hypolimnetic aeration, where water is removed, aerated and returned to its original depth; the latter aims to actually inhibit mixing and preserve the natural biochemical cycling of the water body [1]. A summary of the beneficial effects of destratification can be seen in Figure 2.

Destratification has been proven as an efficient method of cyanobacteria bloom prevention; however, experimental evidence suggests that it may promote diatom growth and does little to reduce total algae populations [9]. Hypolimnetic aeration technologies are well-established and effective at alleviating hypoxic conditions [10], but have been found to be of little benefit in reducing internal phosphorus loading from $\mathrm{P}$ stored in lakebed sediments [11]. As many of these setups use pneumatic technologies, the associated capital costs and energy consumption rates are quite high [12], which limits the applicability of artificial circulation to smaller inland water bodies, such as lakes and reservoirs.

\subsection{Removal of Harmful Species}

Direct removal of the algae biomass in a eutrophic water body provides immediate environmental improvement by addressing both the cause of the algae bloom and its effects on surrounding aquatic life. Nutrients synthesized in the growth of the algae will be removed along with the biomass, thereby providing a pathway for permanent nutrient reduction and addressing the cause of the bloom; the reduction is further enhanced since harvesting a lower-trophic organism such as algae eliminates nutrient loss incurred through upper-level food chain inefficiencies [1]. Algae harvesting will also limit the growth of the heterotrophic bacteria that are the direct cause of hypoxia by removing organic matter [13]. Conventional algae harvesting methods include trawling with plankton nets and traveling screens; a pilot-scale experiment focused on harvesting cyanobacteria in the Baltic Sea was 


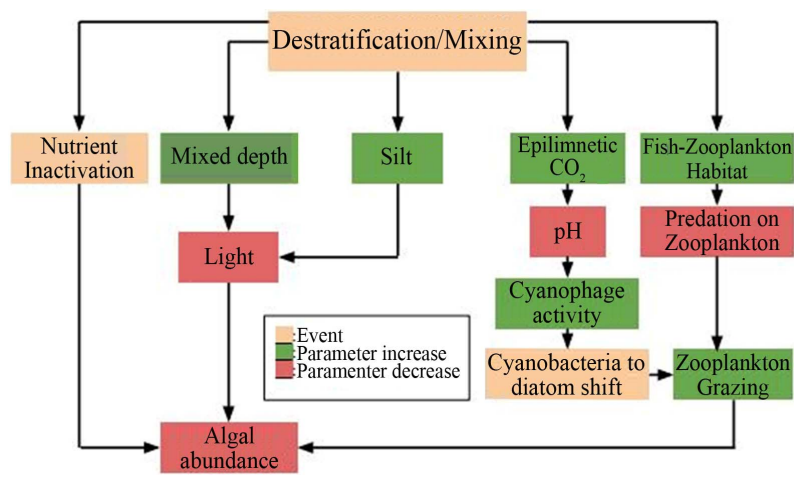

Figure 2. Effects of destratification on aquatic ecosystems (adapted from [1]).

able to scrub $5.5 \mathrm{ha} / \mathrm{hr}$ of sea surface using an oil boom modified with polyester weave forming fabric, a material commonly used in the paper industry [14]. Obvious downsides to algae harvesting are fuel, equipment, and labor costs, particularly when the afflicted area is substantial, as is often the case in cultural eutrophication. However, it has been suggested that the marketability of various algae as protein supplements or bioenergy feedstock may be able to offset some of those costs. The Harvested Algae Biofuel Energy Recovery model (HABER) developed by Kuo [13] found that a harvesting operation in the Gulf of Mexico using plankton net trawling could conceivably break even at standard eutrophic chlorophyll concentrations if the harvested biomass was converted into crude oil by a hydrothermal liquefaction process or into methane via anaerobic digestion. Unfortunately, further environmental analysis also found that the expected biomass harvest amount for this technology would have minimal impact on the overall size of the Gulf hypoxic zone, thus it was suggested that algae harvesting operations may hold more utility for smaller-scale areas, such as lakes and reservoirs experiencing eutrophication.

Copper-based algaecides and chemical flocculants have been used to control algae blooms in many instances; however, these practices may create more environmental problems than they solve [2]. A recent interest in more sustainable treatment methods has led to the exploration of using clay minerals as flocculation agents. Dense clay particles attach to the algae cells and promote conglomeration and sinking, despite the buoyancy of the algae cells [15]. Field tests in Japan and South Korea found that clay sediments were effective in controlling harmful algae blooms and restoring threatened mariculture operations [16]. Concerns regarding the cost of clay transport and the effectiveness of clay flocculation in low-salinity environments have inspired investigation into alternatives; recent work has found that sand modified with biodegradable Moringa oleifera seed extract and chitosan has great flocculation potential in both fresh and saltwater environments [17]. The modified sand flocculant was able to remove over $90 \%$ of three different species of algae in suspension, but its effectiveness has yet to be proven on a large scale.

\subsection{Nutrient Assimilation}

Whereas the previous topics have focused on addressing and mitigating the effects of eutrophication within a water body, nutrient assimilation strategies are focused on "treating" influent water before it is deposited into the water body. The following management techniques are used as preventative, rather than curative, methods in eutrophication and algae bloom control.

\subsubsection{Wetlands}

Wetlands naturally provide a variety of ecological services; foremost among them is nutrient removal. Mechanisms for the removal of nitrogen and phosphorus in a wetland involve either burial in sediment layers or uptake and storage by plants. Riparian vegetation is very effective at removing these nutrients from runoff water, and, if the plants are harvested, their assimilation of the nutrients can be considered a permanent loss pathway. Wetland microbes also facilitate the denitrification process in which $\mathrm{NO}_{3}$ is converted into $\mathrm{N}_{2}$ gas. The natural efficacy of these processes has already been put to use in the Mississippi River delta as a method of combating eutrophication and hypoxia [18].

A hydrodynamic model of nutrient loading in the Maurepus forested wetland in Louisiana was used to assess the nutrient removal potential of a proposed Mississippi River diversion into the wetland [19]. It was estimated that the diversion would result in a $90 \%-95 \%$ reduction of introduced nitrate by the wetlands. Given the anticipated water quality improvements, the study suggested that plans for the diversion move forward. An assessment of the denitrification efficacy of the Breton Sound estuary, a wetland already receiving diverted Mississippi River water, found that average removal rates were between 21 and $32 \mathrm{~g} \mathrm{~N} / \mathrm{m}^{2} / \mathrm{yr}$, which indicated that the estuary was capable of processing significant quantities of nitrate from the Mississippi [20]. Wetlands are so effective at nutrient removal that they are sometimes used as methods of tertiary water treatment, receiving effluent directly from wastewater treatment plants. Conventional tertiary treatments methods are often very expensive; wetland assimilation can provide an effective, low-cost alternative if geographically feasible. Day Jr. et al. [18] compiled a list of different wetland treatment projects undertaken in coastal Louisiana using data compiled from multiple studies of the individual sites. A selection of site-specific data on nutrient removal, as well as estimated cost savings over a 20 -year period (compared to conventional treatment methods) to the communities can be seen in Table 1. 
Table 1. Nutrient removal and cost savings data for two LA wetlands used in tertiary wastewater treatment [18].

\begin{tabular}{ccccccc}
\hline Site & Treatment Basin (ha) & N loading $\left(\mathrm{g} / \mathrm{m}^{2} / \mathrm{yr}\right)$ & P loading $\left(\mathrm{g} / \mathrm{m}^{2} / \mathrm{yr}\right)$ & \%N reduction & \%P reduction & Cost Savings $(\$)$ \\
\hline Breaux Bridge & 1475 & 1.87 & 0.94 & 100 & 80 & $2,636,000$ \\
Thibodaux & 231 & 3.1 & 0.6 & 69 & 66 & 500,000 \\
\hline
\end{tabular}

\subsubsection{High-Rate Algal Ponds}

Microalgae are often hailed as an important "third generation" biofuel source due to their rapid growth rate (often doubling biomass within 24 hours), as well as their high oil content [21]. There are also well-established markets for some species as animal feeds and nutritional supplements. Wastewater treatment utilizing the nutrient uptake abilities of microalgae was first proposed by Oswald and Golueke [22] in the form of a high-rate algae pond (HRAP). HRAPs are shallow, open raceway-style ponds that are typically mixed with a paddlewheel and can cover up to $5000 \mathrm{~m}^{2}$ in large-scale applications [23]. Though perhaps not as cost-effective as natural wetlands (due to capital and construction costs), high-rate algae ponds have potential as a combined source of water treatment and marketable products.

A recently published study examined the possibilities for the inclusion of HRAPs at the Western Treatment Plant in Melbourne, Australia in wastewater treatment and biofuel production [24]. The authors posit that biofuel production from algae can be profitable when wastewater treatment is the primary goal. A spreadsheet economic model found that algae oil of biodiesel quality could be produced for less than $\$ 1 / \mathrm{L}$ (US dollars) when conventional oil extraction techniques were used on a portion of the algal biomass, and the rest was converted into electrical energy by anaerobic digestion. This production cost was said to be possible due to the low-cost water and nutrients readily supplied by the wastewater treatment plant, as well as "free" supplemental carbon dioxide provided by on-site diesel generators. In Castilla y Leon, Spain, two 464 L HRAPs (mixed cultures) were studied for a period of nine months in order to examine their long-term nutrient removal ability when fed with effluent from a pig farm [23]. Nitrogen removed in the biomass ranged from $21 \%-48 \%$. Phosphorus removal efficiencies remained low $(<10 \%)$ for the duration of the study due to the low $\mathrm{pH}$ of the effluent; regardless, the authors claimed that HRAPs hold great promise in the field of waste-to-value pollution control. The potential of microalgae Chlorella vulgaris in removing nitrate-nitrogen from tilapia pond effluent, as well as possibilities for separation of algal biomass (sedimentation or filtration) from the effluent have been examined [25]. The algae were found to have a substrate utilization rate (a measure of nitrogen removed per dry biomass per unit time) of $22.3 \mathrm{mg} \mathrm{N} / \mathrm{g} \mathrm{DW} /$ day. The small cell size of $C$. vulgaris
(2.5 - $12 \mu \mathrm{m})$ lowered the effectiveness of sedimentation and filtration via sieve trays, which led to the conclusion that a more energy-intensive process, such as membrane filtration, may be required to concentrate the biomass.

\section{Integrated Algae-Aquaculture Systems}

As the world population increases, demands on food production will rise. Aquaculture is expected to be the primary source of seafood by 2050 , and it is essential that sustainable methods of production be devised and implemented so that land, water, and nutrients can be used efficiently [26]. Extensive aquaculture systems that utilize algae as a method of capturing excess nutrients and a self-sustaining process input (i.e. fish food) represent an innovative path towards this goal.

In Mbour, Senegal, a prototype aquaculture system was constructed for tilapia production; both algae (Chlorella sp.) and zooplankton (Brachionus plicatilis) were cultivated in wastewater ponds outside the intensive fish tanks, and then distributed to the juvenile tilapia as additional food [27]. A primary feature of this freshwater system was that, with the exception of evaporation losses, water was completely recycled for the duration of this study. The system was able to reach a global productivity $1.85 \mathrm{~kg} / \mathrm{m}^{2} / \mathrm{yr}$ in tilapia biomass, and a nitrogen balance found that $\mathrm{N}$ was assimilated at a rate of $1.90 \mathrm{mg} / \mathrm{L} / \mathrm{day}$. The authors found these results to be comparable to others in the literature for similar systems.

A pilot-scale system focused on reducing water demand via recirculation and fish food production using algae grown in a bioremediation pond was developed and tested [28]. The first units in the system were tanks for the intensive pellet feeding of catfish; water from these tanks flowed into an algae pond, wherein the algae utilized the excess nutrients for growth. Continuous mixing was applied to ensure maximum light exposure. The wet algal biomass was then pumped into a second pond stocked with carp and tilapia, which were not pellet-fed and used the algae as their food source. The system was closed and water was emptied only at the end of the twelve-week study. As expected, the catfish in the intensive tanks had a high yield of $20.25 \mathrm{~kg} / \mathrm{m}^{3}$, while the carp and tilapia in the pond produced 0.12 and $0.38 \mathrm{~kg} / \mathrm{m}^{3}$, respectively. Nutrient retentions of the system during the 12 weeks for nitrogen and phosphorus were $1074 \mathrm{~kg}$ $\mathrm{N} /$ ha and $327 \mathrm{~kg} \mathrm{P} / \mathrm{ha}$, which represented $57.1 \%$ of the $\mathrm{N}$ load and $77.3 \%$ of the P load. These numbers were sig- 
nificantly higher than those reported for other fishponds; the authors posited that nutrient reduction efficiency of their system was greatly improved by the addition of treatment organisms (algae and secondary feeder fish) in two separate ponds.

\section{Design of a Novel System}

\subsection{Overview}

In 2008, the Mississippi River/Gulf of Mexico Watershed Nutrient Task Force, a consortium made up of federal organizations such as the EPA, USGS, USDA, and others, stated a goal of reducing the five-year running average area of the Gulf dead zone to less than 1930 square miles by the year 2015. It was specified that nitrogen and phosphorus nutrient loads would each need to be reduced by about $45 \%$ with respect to $1980-1996$ levels in order to reach this goal. The Task Force aims to accomplish this through a combination of source reduction and remediation techniques spearheaded by their various constituent organizations [29]. The design presented here was devised with the intent to assist in the achievement of the aforementioned goal by providing a nutrient assimilation service, while also providing marketable products in the form of algal biomass and tilapia.

This concept for this design was inspired by the efficiency of both wetlands and water treatment by microalgae in nutrient load reduction projects, and it combines certain aspects of both remediation technologies with an aquaculture operation. In a manner similar to a wetland project, all water for this system would be sourced directly from the Mississippi River via a diversion. A series of screen filters would remove debris from the incoming water, which would then enter into a fish pond for extensive rearing of tilapia. Effluent from the fish pond, still containing nutrients from the Mississippi, would be emptied into a large raceway pond system, similar to the HRAPs described by Park et al. [30]. In order to minimize costs and energy usage, pure carbon dioxide will not be piped into the pond; the paddlewheel mixing system will be counted upon to facilitate mass transfer of $\mathrm{CO}_{2}$ into the water. The HRAP will be inoculated by a smaller separate vessel housing a pure culture of Chlorella microalgae. Following the pond system, algae biomass will be physically separated from the water using a cross-flow filtration system. A portion of wet biomass will be sent back to the fish ponds as feed, while the residual biomass will be sent to further processing and converted into a marketable product. Effluent water, now with reduced nutrient loads, will be sent back into the Mississippi. Figure 3 shows a basic process flow diagram (PFD) of the system; unit operations are discussed in detail in the following sections of the paper.

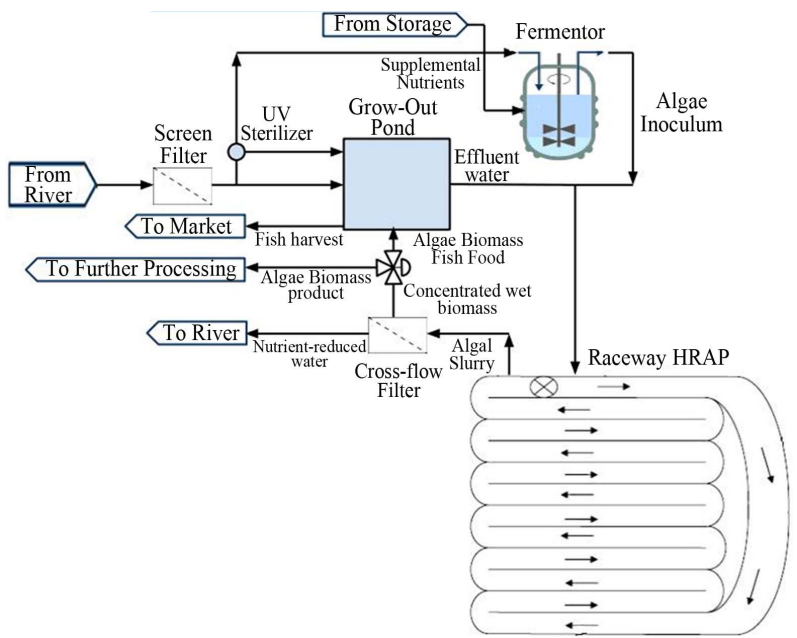

Figure 3. PFD of integrated algae-aquaculture system (HRAP image credit: [31]).

\subsection{Fish Ponds}

In extensive aquaculture, fish are cultivated without supplemental feeding. As the diet of tilapia naturally consists of algae, they are a convenient choice for extensive algae-aquaculture systems like the one developed by Gal et al. [28]. They are also a marketable commodity, having recently become the most popular farmed fish in the United States [32]. In the proposed system, tilapia will be stocked in an extensive fish pond where their only food source is the algal biomass harvested from the HRAP. Apportionment of the concentrated wet biomass stream will be determined based on the nutrient requirements of the fish.

Extensive feeding is reported to yield best results for tilapia ponds stocked with densities at or below 4,000/ acre [33]. Assuming a pond depth of 1 meter, an area of 1 acre, and an initial stocking weight of $29 \mathrm{~g} /$ fish, it was determined that biomass density at stocking $\left(B_{i}\right)$ should be roughly $0.029 \mathrm{~kg} / \mathrm{m}^{3}$. Based on this stocking value in a $1 \mathrm{~m}$-deep pond, a model was developed to test the effect of different pond areas on fish production and algae consumption over time.

Total tilapia biomass at a given time in $\mathrm{kg} / \mathrm{m}^{3}\left(B_{f}\right)$ can be represented by Equation (1), where $n$ is the culture period in days and $i$ is the daily rate of increase of biomass (DRIB, measured in percent) divided by 100 [34]. Coche [34] lists multiple studies of extensive tilapia cultures that have DRIBs ranging from $1.7 \%-4.8 \%$; for the purposes of this estimation, a DRIB of $3 \%$ was assumed.

$$
B_{f}=B_{i}(1+i)^{n}
$$

$B_{f}$ and the pond volume can be used to calculate the total kilograms of fish present in the pond, and, assuming uniform mass and negligible spawning, the mass per fish. 
Understandably, as the fish mature, they will require greater amounts of food; a study on wild tilapia [35] yielded a linear relationship between the weight of a single fish in grams $(x)$ and its daily algae intake in milligrams $(y)$, seen below in Equation (2). The daily algae intake was assumed to be the same for all fish and multiplied by the total number of fish to obtain the total algae biomass requirement for the fish pond in $\mathrm{kg} / \mathrm{d}$.

$$
y=271+13.3 x
$$

A culture period of 100 days was assumed based on harvesting recommendations in [33]. At harvest time, the pond will be partially drained and seine nets with a 1inch mesh will be used to capture the fish. The amount of labor required for this task is dependent on the optimal pond area. In addition, the authors advocate a pond size between $1-10$ acres for extensive operations; for ease of management, a 5 -acre pond was decided upon for this design. The tilapia-algae relationship for such a pond over the recommended culture period can be observed in Figure 4.

\subsection{Pure Culture Inoculum Reactor}

One method of algae ecosystem management is to seed the system with a desirable species of algae that can be produced in pure culture. Continuous seeding may be sufficient to control concentrations of algae or cyanobacteria that produce toxins.

Photobioreactors are commonly used for algae cultivation on a small scale; however, though many innovative designs are being tested [36], photobioreactors often must be highly specialized for the task at hand and can prove costly to operate [37]. If an algae can grow in heterotrophic conditions (which Chlorella can), it is often considerably more economical and efficient to produce the algae in a fermentor; reasons for this include both the elimination of photosynthetic inefficiencies as well as a large pre-existing knowledge base regarding fermentor operation [38]. Heterotrophic growth has also been proven to be an effective method to produce inoculum for large-scale phototrophic algae ponds due to its high productivity $[39,40]$. Taking this information into consideration, it was determined that a fermentor would be the best choice for the pure culture inoculum reactor.

Kinetics parameters in the fermentor were modeled after the results of experiments in [39] on the heterotrophic growth of Chlorella using molasses as a carbon source and yeast extract as a nitrogen source. The highest maximum biomass concentration on a dry weight basis $(\mathrm{X})$ and specific growth rate $(\mu)$ obtained in the study occurred for a molasses concentration of $20 \mathrm{~g} / \mathrm{L}$ and a yeast extract concentration of $6 \mathrm{~g} / \mathrm{L}$. These parameters were taken as the basis for calculation, since the goal of inoculation is to add as high a concentration of biomass

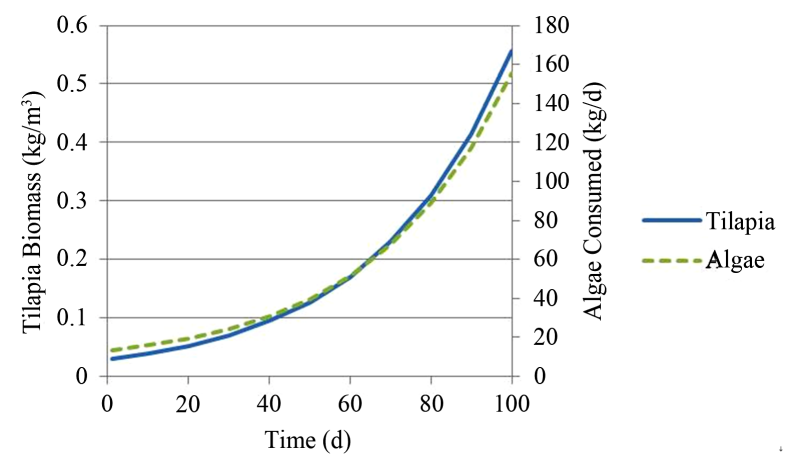

Figure 4. Relationship between tilapia biomass and algae consumption requirements in a 5-acre extensive fishpond.

as possible to the raceway pond so that the Chlorella growth will not be overtaken by less desirable species of algae. However, assuming the yeast extract was approximately $10 \%$ nitrogen [41] and the mean total $N$ concentration in the Mississippi River is $2.26 \mathrm{mg} / \mathrm{L}$ [42], we would need to increase nitrogen concentration in the incoming water substantially $(\sim 26,450 \%)$ in order to match their experimental conditions. Thus, supplemental $\mathrm{N}$ will have to be added along with the molasses. Seeding of the raceway is intended to be continuous, so the fermentor will be at steady-state; thus the specific growth rate is equal to the dilution rate $(D)$. This value, along with an assumed medium flow rate $(F)$ can be used to calculate volume of the reactor $\left(V_{F}\right)$ and the mean residence time $(\tau)$. All results can be seen in Table 2 .

As contamination is a primary concern when preparing a pure culture, an ultraviolet sterilizer will treat the river water before it enters the fermentor.

\subsection{Raceway High-Rate Algae Pond}

The raceway pond is where the system will perform its primary function of nutrient assimilation. Unless a lowcost source of $\mathrm{CO}_{2}$, such as a coal-fired power plant, is located near the pond, it will be assumed that paddlewheel mixing and turbulence will be the sole facilitators of mass transfer for the system. When performing design calculations for the HRAP, multiple equations found in a reference text [43] were used. Equation (3) is Manning's equation, where $V$ is the mean velocity $(\mathrm{m} / \mathrm{s}), R$ is the mean hydraulic radius (m), $S$ is the rate of energy loss per unit length (dimensionless; can be split into $\Delta d / L$ ), and $n$ is Manning's friction coefficient $\left(\mathrm{s} / \mathrm{m}^{1 / 3}\right)$. Equation (4) is an equation developed from empirical observation of large-scale open pond algae cultures where $C_{C}$ is the light-limited algae concentration on a dry weight basis $(\mathrm{mg} / \mathrm{L})$ and $d$ is the pond depth in centimeters. Equation (5) is obtained from a differential mass balance on the pond where $C_{0}$ is entering concentration, $\mu$ is specific growth rate, and $t_{r}$ is retention time. Equation (6) is the standard dilution equation, adapted for the transition of 
Table 2. Inoculum fermentor kinetics parameters with molasses concentration of $20 \mathrm{~g} / \mathrm{L}$ and total $\mathrm{N}$ concentration of $0.60 \mathrm{~g} / \mathrm{L}$.

\begin{tabular}{cccccc}
\hline$\mu(1 / \mathrm{hr})$ & $D(1 / \mathrm{hr})$ & $F(\mathrm{~L} / \mathrm{hr})$ & $V_{F}(\mathrm{~L})$ & $\tau(\mathrm{hr})$ & $X(\mathrm{mg} / \mathrm{L})$ \\
\hline 0.023 & 0.023 & 2.3 & 100 & 44 & 7180 \\
\hline
\end{tabular}

algal biomass between the fermentor and the HRAP where $V_{F}$ is volume of the fermentor, $V_{P}$ is volume of the pond, and $X$ is the concentration exiting the fermentor.

$$
\begin{gathered}
V=\frac{1}{n} R^{2 / 3} S^{1 / 2} \\
C_{C}=9000 / d \\
\operatorname{In} \frac{C_{C}}{C_{0}}=\mu t_{r} \\
X V_{F}=C_{0} V_{P}
\end{gathered}
$$

In order to perform design calculations, a number of parameters had to be estimated or set. Assuming an asphalt lining for the pond, $n$ was set to $0.015 \mathrm{~s} / \mathrm{m}^{1 / 3}$. The $\Delta d$ component was assumed to be $0.5 d$. Pond dimensions were set at $3 \mathrm{~m}$ wide and $30 \mathrm{~cm}$ deep, which made $R=0.25 \mathrm{~m}$. Using that depth, Equation 4 yields a maximum light-limited concentration of $300 \mathrm{mg} / \mathrm{L}$. Specific growth rate in the pond was estimated at 0.6/day [25]. Inoculum concentration $C_{0}\left(X\right.$ diluted to $\left.V_{P}\right)$ was unknown, since the pond length was also undetermined. Iterative calculations to solve for unknowns were performed in the following manner (results follow):

- Value guessed for $C_{0}$ and pond retention time solved for using Equation (5) ( $\tau$ doubled to account for the fact that Attasat et al.'s growth rate assumed constant illumination).

- Equation (3) algebraically manipulated (assuming $V$ $=L / t_{r}$ ) to solve for pond length $L$, which was then used to calculate the required pond area.

- $L$ calculated separately by Equation (6) using the width and depth of the pond.

- Residual between $L$ values minimized by new value for $C_{0}$.

\subsection{Biomass Separation}

There are many different methods for dewatering and concentrating algal biomass, and they vary greatly in both cost of implementation and energy consumption [44]. For the purposes of this initial design, preference was given to processes that would minimize the use of chemical coagulants and electricity (even if higher cost was incurred); as one of the primary goals of this project is sustainable water treatment for the lower Mississippi, it seemed counterintuitive to suggest processes that involve adding more chemicals to the water right before discharging it back into the river. Under these constraints, it was postulated that cross-flow filtration may be the best option for this process. A diagram of a cross-flow filtration apparatus can be seen in Figure 5.

Cross-flow filtration is a conventional purification method in which a pressure gradient forces a fluid mixture flowing across a membrane to separate; it has been successfully utilized for separation of microalgae slurry [46], and an economic study of its utility in an industrialscale algal dewatering process estimated costs at around $\$ 0.75 / \mathrm{kg}$ dry biomass [47]. Cheaper options exist when chemical pretreatment of the algae slurry or dynamic filtration using a rotor are considered; however, those practices may not support the project's goal of minimal environmental impact.

Once separated, the filtered water will be discharged back into the Mississippi. The concentrated biomass will now be split into two streams: one for further processing, and one to return to the fish pond as food. Since the tilapia require greater amounts of food as they mature, the portion of algal biomass returning to the extensive pond will be adjusted daily according to the nutrient requirements calculated by the model.

\subsection{Further Processing}

There are a number of options for processing the residual algal biomass into a marketable product. Markets exist for the algae biomass to be directly sold as an agricultural feed [48,49]; however, increased transportation costs would have to be taken into consideration if this avenue was to be pursued. Also, quality assurance procedures would have to be implemented in order to ensure food safety [50].

Many algae-based operations aim to produce bio-energy in their processes; three different methods of algal biomass conversion were considered for this system (see Table 3).

Dewatering and drying are typically the most costly aspects of any algae-to-energy process-drying alone usually accounts for $70 \%-75 \%$ of the entire production cost [44]. Dewatering is already built into the proposed design through the use of cross-flow filters; regardless, in keeping with the sustainability goals of this project, it

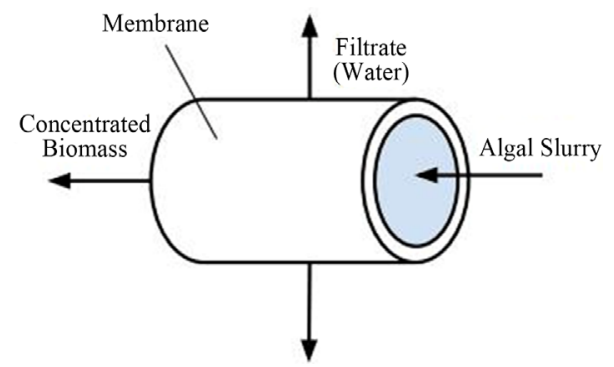

Figure 5. Cross-flow filtration unit (adapted from [45]). 
Table 3. Analysis of algal bio-energy conversion methods.

\begin{tabular}{ccccc}
\hline Method & Product & $\begin{array}{c}\text { Drying } \\
\text { Required? }\end{array}$ & $\begin{array}{c}\text { Net Energy } \\
\text { Yield }\end{array}$ & $\begin{array}{c}\text { Relative } \\
\text { Cost }\end{array}$ \\
\hline Transesterification & Biodiesel & Yes & Low & High \\
$\begin{array}{c}\text { Anaerobic } \\
\text { Digestion }\end{array}$ & Biogas & Yes & High & Low \\
$\begin{array}{c}\text { Hydrothermal } \\
\text { Liquefaction }\end{array}$ & Bio-crude oil & No & High & Low \\
\hline
\end{tabular}

Sources: [13,51,52].

would be prudent to consider only those processes which minimize energy input and cost. From that standpoint, anaerobic digestion or hydrothermal liquefaction may be the best choices if energy is determined to be the highest-value product attainable from the algal biomass. Further research is required to determine the cost of implementation for said processes, as well as the market price of their products.

\subsection{Expected Productivity}

The theoretical maximum algae biomass productivity in $\mathrm{g} / \mathrm{m}^{2} /$ day $\left(P_{\max }\right)$, assuming ideal conditions, can be estimated using Equation (4), where $I_{0}$ is the average solar radiation in $\mathrm{MJ} / \mathrm{m}^{2} /$ day, $\eta_{\max }$ is the maximum efficiency of photosynthetic conversion of solar energy, and $H$ is the energy value of the algal biomass in $\mathrm{kJ} / \mathrm{g}[30]$.

$$
P_{\max }=\frac{I_{0} \eta_{\max }}{H} \times 1000
$$

Average solar radiation for the Mississippi delta area is approximately $16.2 \mathrm{MJ} / \mathrm{m}^{2} /$ day [53]; using this value along with $\eta_{\max }=2.4 \%$ and $H=21 \mathrm{~kJ} / \mathrm{g}$ [30], it was estimated that the maximum areal productivity for a HRAP system in that region would be about $18.5 \mathrm{~g} / \mathrm{m}^{2} /$ day. Taking the previously calculated area into account, this would mean that the proposed system would have a maximum biomass productivity of $5487 \mathrm{~kg} /$ day.

As previously mentioned, the fish will be harvested every 100 days. According to the tilapia growth model, total mass of fish at harvest time will be (under ideal conditions) approximately $11,277 \mathrm{~kg}$. Assuming a tilapia market price at $\$ 3 / \mathrm{kg}$ [54], this will translate to an income of almost $\$ 123,500$ per year from the aquaculture aspect of the project.

\subsection{Processing Capacity and Expected Nutrient Load Reduction}

The average discharge rate of the Mississippi River is estimated to be around $17,000 \mathrm{~m}^{3} / \mathrm{s}$ [55]. The volumetric flow rate in a channel $(Q)$ can be determined using Equation (8) [43]. Upon comparison of the flow in the HRAP and the discharge rate of the river, it appears that the proposed design would have the capacity to process ap- proximately $0.000173 \%$ of the Mississippi River discharge.

$$
Q=w d V
$$

Nutrient retentions of $1074 \mathrm{~kg} \mathrm{~N} / \mathrm{ha}$ and $327 \mathrm{~kg} \mathrm{P} / \mathrm{ha}$ from the algae-aquaculture system described in [28] were used as the basis for estimation regarding nutrient load reduction potential of the proposed system. The retention rates were converted into yearly rates per hectare assuming the twelve-week study could be extrapolated out to one year. The area of the proposed HRAP was used to calculate the yearly nutrient removal potential. In order to determine annual nutrient removal percentages, these rates were then compared to the mean nutrient fluxes delivered from the Mississippi to the Gulf of Mexico for the period of 1980-1996: 1,567,900 metric tons/yr of nitrogen and 136,500 metric tons/yr of phosphorus [42]. Results can be seen in Table 4.

There are many locations along the Mississippi where integrated algae-aquaculture systems may be designed and operated to remove nutrients and harvest fish. River water can be diverted through constructed lakes with flow controlled by gates that restrict that amount of water that enters the lake. The nutrient removal percentages calculated here may not represent valid predictions for systems implemented further upstream, since mean nutrient fluxes vary along the length of the river.

\section{Discussion}

Though these removal percentages are a far cry from the $45 \%$ reductions recommended by the Mississippi River/ Gulf of Mexico Watershed Nutrient Task Force, it is worth noting that the proposed design will be more efficient per unit area at nutrient removal than the wetland projects discussed earlier. The added value products of tilapia and algal biomass may be able to offset capital and maintenance costs of the facility, and perhaps even allow for a profitable enterprise. Further research, particularly into the comparative costs of algae-to-energy processes, is needed to investigate the economic viability of the system proposed in this paper. This system may have utility in enclosed freshwater environments as well; the nutrient loads entering lakes and reservoirs will not be as massive as those entering the Gulf, therefore, the system will provide greater net reductions of nitrogen and phosphorus when used to treat influent to smaller water bodies.

A scaled-down alternative to the algae-aquaculture system may also be the construction and improved maintenance of farm ponds and recreational lakes throughout the watershed of a eutrophic ecosystem. If these manmade water bodies are built to cultivate algae and tilapia in a single environment, they will be able to provide nu- 
Table 4. Raceway pond nutrient load reduction.

\begin{tabular}{cccc}
\hline $\begin{array}{c}N \text { removal rate } \\
(\mathrm{kg} / \mathrm{yr})\end{array}$ & $\begin{array}{c}P \text { removal rate } \\
(\mathrm{kg} / \mathrm{yr})\end{array}$ & $\begin{array}{c}\% N \text { removed } \\
\text { annually }\end{array}$ & $\begin{array}{c}\% P \text { removed } \\
\text { annually }\end{array}$ \\
\hline 138,415 & 42,143 & 0.00883 & 0.0309 \\
\hline
\end{tabular}

trient removal services and marketable products, as well as catchment areas for flooding and storm water management. Biomanipulation, artificial circulation, and algae harvesting may prove to be useful tools in smaller, less complex aquatic ecosystems such as these. Productive reservoir/lake/pond ecosystems involving fish and algae represent permanent nutrient loss pathways, since the organisms that take up the nutrients are being harvested and removed from the system; case studies often attest to the natural nutrient uptake abilities of these ecosystems [56]. If enough of these water bodies are constructed and maintained, their cumulative effect may be substantial. Preliminary calculations indicate that approximately $1,850,000$ hectares of such productive ecosystems would be needed to reduce the annual Mississippi River phosphorus load by $50 \%$. Further research is required to gauge the cost-effectiveness and feasibility of constructing and maintaining pond/lake ecosystems compared to algae-aquaculture systems similar to the one proposed herein.

One of the significant aspects of ecosystem management is that of finding methods to allocate costs and pay for each project. The reduction of nitrogen and phosphorus associated with an algae-aquaculture system has value to society, but methods to convert this value to project funding may require government action.

\section{Conclusion}

The proposed integrated algae-aquaculture system was developed from knowledge of existing technologies and techniques for sustainable eutrophication management. The mitigation strategies discussed in this paper will be most effective when coupled with a comprehensive nutrient control strategy that addresses the sources of anthropogenic nutrient loading in the watershed of a eutrophic water body. Benefits of improved eutrophication management include more productive ecosystems, increased real estate values, fewer taste and odor issues in reservoirs, and greater recreational usage of water bodies. It is our hope that the ideas presented in this paper can be utilized and expanded upon in order to create synergistic strategies that allow eutrophication management to become a successful, cost-effective, and sustainable enterprise.

\section{Acknowledgements}

Financial support for this project was provided by the
National Science Foundation through award EEC1156549. We would like to thank Dr. Walter K. Dodds for his assistance with the project. The Process Flow Diagram drawing template from

EngineeringToolBox.com was used in developing Figure 3.

\section{REFERENCES}

[1] B. Henderson-Sellers and H. R. Markland, "Decaying Lakes: The Origins and Control of Cultural Eutrophication," John Wiley \& Sons Ltd., Hoboken, 1987.

[2] W. K. Dodds, "Chapter 17: Trophic State and Eutrophication" In: Thorp, J.H., Ed., Freshwater Ecology: Concepts and Environmental Applications, Academic Press, San Diego, 2002, pp. 337-365,391-410.

[3] National Oceanic and Atmospheric Administration, "Economic Impacts of Harmful Algal Blooms," 2008.

http://www.cop.noaa.gov/stressors/extremeevents/hab/cur rent/econimpact_08.pdf

[4] W. K. Dodds, W. W. Bouska, J. L. Eitzmann, T. J. Pilger, K. L. Pitts, A. J. Riley, J. T. Schloesser and D. J. Thornbrugh, "Eutrophication of U.S. Freshwaters: Analysis of Potential Economic Damages," Environmental Science \& Technology, Vol. 43, No. 1, 2009, pp. 12-19. http://dx.doi.org/10.1021/es801217q

[5] E. Jeppesen, M. Søndergaard, N. Mazzeo, M. Meerhoff, C. C. Branco, V. Huszar and F. Scasso, "Lake Restoration and Biomanipulation in Temperate Lakes: Relevance for Subtropical and Tropical Lakes," In: V. Reddy, Ed., Restoration and Management of Tropical Eutrophic Lakes, Science Publishers, Enfield, 2005, pp. 331-349.

[6] G. Closs, B. Downes and A. Boulton, "Freshwater Ecology: A Scientific Introduction," Blackwell Science Ltd., Malden, 2004.

[7] E. Jeppesen, M. Meerhoff, B. A. Jacobsen, R. S. Hansen, M. Søndergaard, J. P. Jensen, T. L. Lauridsen, N. Mazzeo and C. W. C. Branco, "Restoration of Shallow Lakes by Nutrient Control and Biomanipuation-The Successful Strategy Varies with Lake Size and Climate," Hydrobiologia, Vol. 581, No. 1, 2007, pp. 269-285. http://dx.doi.org/10.1007/s10750-006-0507-3

[8] C. C. Figueredo and A. Giani, "Ecological Interactions between Nile Tilapia (Oreochromis niloticus, L.) and the Phytoplanktonic Community of the Furnas Reservoir (Brazil)," Freshwater Biology, Vol. 50, No. 8, 2005, pp. 1391-1403. http://dx.doi.org/10.1111/j.1365-2427.2005.01407.x

[9] W.-M. Heo and B. Kim, "The Effect of Artificial Destratification on Phytoplankton in a Reservoir," Hydrobiologia, Vol. 524, No. 1, 2004, pp. 229-239.

http://dx.doi.org/10.1023/B:HYDR.0000036142.74589.a4

[10] A. W. Fast and M. W. Lorenzen, "Synoptic Survey of Hypolimnetic Aeration," Journal of the Environmental Engineering Division, Vol. 102, No. 6, 1976, pp. 11611173.

[11] R. Gächter and B. Wehrli, "Ten Years of Artificial Mixing and Oxygenation: No Effect on the Internal Phos- 
phorus Loading of Two Eutrophic Lakes," Environmental Science \& Technology, Vol. 32, No. 23, 1998, pp. 36593665. http://dx.doi.org/10.1021/es9804181

[12] A. W. Fast, M. W. Lorenzen and J. H. Glenn, "Comparative Study with Costs of Hypolimnetic Aeration," Journal of the Environmental Engineering Division, Vol. 102, No. 6, 1976, pp. 1175-1187.

[13] C.-T. Kuo, "Harvesting Natural Algal Blooms for Concurrent Biofuel Production and Hypoxia Mitigation," M.S. Thesis, University of Illinois at Urbana-Champagne, Urbana, 2010.

[14] F. Gröndahl, "Removal of Surface Blooms of the Cyanobacteria Nodularia spumigena: A Pilot Project Conducted in the Baltic Sea," Ambio, Vol. 38, No. 2, 2009, pp. 79-84. http://dx.doi.org/10.1579/0044-7447-38.2.79

[15] M. Sengco and D. M. Anderson, "Controlling Harmful Algal Blooms through Clay Flocculation," Journal of Eukaryote Microbiology, Vol. 51, No. 2, 2004, pp. 169172. http://dx.doi.org/10.1111/j.1550-7408.2004.tb00541.x

[16] R. H. Pierce, M. S. Henry, C. J. Higham, P. Blum, M. R. Sengco and D. M. Anderson, "Removal of Harmful Algal Cells (Karenia brevis) and Toxins from Seawater Culture by Clay Flocculation," Harmful Algae, Vol. 3, No. 2, 2004, pp. 141-148. http://dx.doi.org/10.1016/j.hal.2003.09.003

[17] L. Li and G. Pan, "A Universal Method for Flocculating Harmful Algal Blooms in Marine and Fresh Waters Using Modified Sand," Environmental Science \& Technology, Vol. 47, No. 9, 2013, pp. 4555-4562. http://dx.doi.org/10.1021/es305234d

[18] J. W. Day Jr., J.-Y. Ko, J. Rybczyk, D. Sabins, R. Bean, G. Berthelot, C. Brantley, L. Cardoch, W. Conner, J. N. Day, A. J. Englande, S. Feagley, E. Hyfield, R. Lane, J. Lindsey, J. Mistich, E. Reyes and R. Twilley, "The Use of Wetlands in the Mississippi Delta for Wastewater Assimilation: A Review," Ocean and Coastal Management, Vol. 47, 2004, pp. 671-691. http://dx.doi.org/10.1016/j.ocecoaman.2004.12.007

[19] R. R. Lane, H. S. Mashriqui, G. P. Kemp, J. W. Day, J. N. Day and A. Hamilton, "Potential Nitrate Removal from a River Diversion into a Mississippi Delta Forested Wetland," Ecological Engineering, Vol. 20, No. 3, 2003, pp. 237-249.

http://dx.doi.org/10.1016/S0925-8574(03)00043-0

[20] R. D. Delaune and A. Jugsujinda, "Denitrification Potential in a Louisiana Wetland Receiving Diverted Mississippi River Water," Chemistry and Ecology, Vol. 19, No. 6, 2003, pp. 411-418. http://dx.doi.org/10.1080/02757540310001618820

[21] Y. Chisti, "Biodiesel from Microalgae," Biotechnology Advances, Vol. 25, No. 3, 2007, pp. 294-306. http://dx.doi.org/10.1016/j.biotechadv.2007.02.001

[22] W. J. Oswald and C. G. Golueke, "Biological Transformation of Solar Energy," Advances in Applied Microbiology, Vol. 2, 1960, pp. 223-262. http://dx.doi.org/10.1016/S0065-2164(08)70127-8

[23] I. de Godos, S. Blanco, P. A. Garcia-Encina, E. Becares and R. Munoz, "Long-term Operation of High Rate Algal
Ponds for the Bioremediation of Piggery Wastewaters at High Loading Rates," Bioresource Technology, Vol. 100, No. 19, 2009, pp. 4332-4339. http://dx.doi.org/10.1016/j.biortech.2009.04.016

[24] D. Batten, T. Beer, G. Freischmidt, T. Grant, K. Liffman, D. Paterson, T. Priestley, L. Rye and G. Threlfall, "Using Wastewater and High-Rate Algal Ponds for Nutrient Removal and the Production of Bioenergy and Biofuels," Water Science \& Technology, Vol. 67, No. 4, 2013, pp. 915-924. http://dx.doi.org/10.2166/wst.2012.618

[25] S. Attasat, P. Wanichpongpan and W. Ruenglertpanyakul, "Cultivation of Microalgae (Oscillatoria okeni and Chlorella vulgaris) using Tilapia-Pond Effluent and a Comparison of their Biomass Removal Efficiency," Water Science \& Technology, Vol. 67, No. 2, 2013, pp. 271-277. http://dx.doi.org/10.2166/wst.2012.505

[26] J. S. Diana, H. S. Egna, T. Chopin, M. S. Peterson, L. Cao, R. Pomeroy, M. Verdegem, W. T. Slack, M. G. Bondad-Reantaso and F. Cabello, "Responsible Aquaculture in 2050: Valuing Local Conditions and Human Innovations will be Key to Success," BioScience, Vol. 63, No. 4, 2013, pp. 255-262. http://dx.doi.org/10.1525/bio.2013.63.4.5

[27] S. Gilles, L. Fargier, X. Lazzaro, E. Baras, N. De Wilde, C. Drakides, C. Amiel, B. Rispal and J.-P. Blancheton, "An Integrated Fish-Plankton Aquaculture System in Brackish Water," Animal, Vol. 7, No. 2, 2013, pp. 322329. http://dx.doi.org/10.1017/S1751731112001279

[28] D. Gal, F. Pekar, E. Kerepeczki and L. Varadi, "Experiments on the Operation of a Combined AquacultureAlgae System," Aquaculture International, Vol. 15, No. 3-4, 2007, pp. 173-180. http://dx.doi.org/10.1007/s10499-007-9089-y

[29] Mississippi River/Gulf of Mexico Watershed Nutrient Task Force, "Gulf Hypoxia Action Plan 2008 for Reducing, Mitigating, and Controlling Hypoxia in the Northern Gulf of Mexico and Improving Water Quality in the Mississippi River Basin,” Washington, DC, 2008.

[30] J. B. K. Park, R. J. Craggs and A. N. Shilton, "Wastewater Treatment High Rate Algal Ponds for Biofuel Production," Bioresource Technology, Vol. 102, No. 1, 2011, pp. 35-42. http://dx.doi.org/10.1016/j.biortech.2010.06.158

[31] I. Rawat, R. Ranjith Kumar, T. Mutanda and F. Bux, "Dual Role of Microalgae: Phycoremediation of Domestic Wastewater and Biomass Production for Sustainable Biofuels Production," Applied Energy, Vol. 88, No. 10, 2011, pp. 3411-3424.

http://dx.doi.org/10.1016/j.apenergy.2010.11.025

[32] E. Rosenthal, "Another Side of Tilapia, the Perfect Factory Fish," The New York Times, 2 May 2011, p. A6.

[33] J. E. Rakocy and A. S. McGinty, "Pond Culture of Tilapia," 1989.

https://srac.tamu.edu/index.cfm/event/getFactSheet/which factsheet $/ 50 /$

[34] A. G. Coche, "Cage Culture of Tilapias," In: R. S. V. Pullin and R. H. Lowe-McConnell, Eds., The Biology and Culture of Tilapias: ICLARM Conference Proceedings 7, International Center for Living Aquatic Resources 
Management, Manila, 1982, pp. 205-246.

[35] C. M. Moriarty and D. J. W. Moriarty, "Quantitative Estimation of the Daily Ingestion of Phytoplankton by Tilapia nilotica and Haplochromis nigripinnis in Lake George, Uganda," Journal of Zoology, Vol. 171, No. 1, 1973 , pp. $15-23$.

http://dx.doi.org/10.1111/j.1469-7998.1973.tb07513.x

[36] D. Briassoulis, P. Panagakis, M. Chionidis, D. Tzenos, A. Lalos, C. Tsinos, K. Berberidis and A. Jacobsen, "An Experimental Helical-Tubular Photobioreactor for Continuous Production of Nannochloropsis sp.," Bioresource Technology, Vol. 101, No. 17, 2010, pp. 6768-6777. http://dx.doi.org/10.1016/j.biortech.2010.03.103

[37] K. K. Vasumathi, M. Premalatha and P. Subramanian, "Parameters Influencing the Design of Photobioreactor for the Growth of Microalgae," Renewable and Sustainable Energy Reviews, Vol. 16, No. 7, 2012, pp. 54435450. http://dx.doi.org/10.1016/j.rser.2012.06.013

[38] P. W. Behrens, "Chapter 13: Photobioreactors and Fermentors: The Light and Dark Sides of Growing Algae," In: R. A. Anderson, Ed., Algal Culturing Techniques, Elsevier Academic Press, Burlington, 2005, pp. 189-203.

[39] R. Leesing and S. Kookkhunthod, "Heterotrophic Growth of Chlorella sp. KKU-S2 for Lipid Production using Molasses as a Carbon Substrate," International Proceedings of Chemical, Biological, and Environmental Engineering, Vol. 9, 2011, pp. 87-91.

[40] Y. Zheng, Z. Chi, B. Lucker and S. Chen, "Two-Stage Heterotrophic and Phototrophic Culture Strategy for Algal Biomass and Lipid Production," Bioresource Technology, Vol. 103, No. 1, 2012, pp. 484-488. http://dx.doi.org/10.1016/j.biortech.2011.09.122

[41] Acumedia Manufacturers, "Yeast Extract 7184," 2011. http://www.neogen.com/Acumedia/pdf/ProdInfo/7184_PI .pdf

[42] D. A. Goolsby, W. A. Battaglin, G. B. Lawrence, R. S. Artz, B. T. Aulenbach, R. P. Hooper, D. R. Keeney and G. J. Stensland, "Flux and Sources of Nutrients in the Mississippi-Atchafalaya River Basin: Topic 3 Report for the Integrated Assessment on Hypoxia in the Gulf of Mexico," NOAA Coastal Ocean Program Decision Analysis Series 17, NOAA Coastal Ocean Program, Silver Spring, Maryland, 1999.

[43] M. A. Borowitzka, "Chapter 14: Culturing Microalgae in Outdoor Ponds,” In: Anderson, R.A., Ed., Algal Culturing Techniques, Elsevier Academic Press, Burlington, 2005, pp. 205-18.

[44] K. Y. Show, D. J. Lee and J. S. Chang, "Algal Biomass Dehydration," Bioresource Technology, Vol. 135, 2013, 720-729. http://dx.doi.org/10.1016/j.biortech.2012.08.021

[45] S. Wronsky, E. Molga and L. Rudniak, "Dynamic Filtration in Biotechnology," Bioprocess Engineering, Vol.
4, No. 3, 1989, pp. 99-104. http://dx.doi.org/10.1007/BF00369757

[46] X. Zhang, Q. Hu, M. Sommerfeld, E. Puruhito and Y. Chen, "Harvesting Algal Biomass for Biofuels Using Ultrafiltration Membranes," Bioresource Technology, Vol. 101, No. 14, 2010, pp. 5297-5304.

http://dx.doi.org/10.1016/j.biortech.2010.02.007

[47] S. D. Rios, J. Salvado, X. Farriol and C. Torras, "Antifouling Microfiltration Strategies to Harvest Microalgae for Biofuel," Bioresource Technology, Vol. 119, 2012, pp. 406-418. http://dx.doi.org/10.1016/j.biortech.2012.05.044

[48] P. Spolaore, C. Joannis-Cassan, E. Duan and A. Isambert, "Review: Commercial Applications of Microalgae," Journal of Bioscience and Bioengineeering, Vol. 101, No. 2, 2006, pp. 87-96. http://dx.doi.org/10.1263/jbb.101.87

[49] J. A. Stamey, D. M. Shepherd, M. J. de Veth and B. A. Corl, "Use of Algae or Algal Oil Rich in n-3 Fatty Acids as a Feed Supplement for Dairy Cattle," Journal of Dairy Science, Vol. 95, No. 9, 2012, pp. 5269-5275. http://dx.doi.org/10.3168/jds.2012-5412

[50] A. G. Day, D. Brinkmann, S. Franklin, K. Espina, G. Rudenko, A. Roberts and K. S. Howse, "Safety Evaluation of a High-Lipid Algal Biomass from Chlorella protothecoides," Regulatory Toicology and Pharmacology, Vol. 55, No. 2, 2009, pp. 166-180. http://dx.doi.org/10.1016/j.yrtph.2009.06.014

[51] P. E. Wiley, J. E. Campbell and B. McKuin, "Production of Biodiesel and Biogas from Algae: A Review of Process Train Options," Water Environment Research, Vol. 83, No. 4, 2011, 326-338. http://dx.doi.org/10.2175/106143010X12780288628615

[52] G. Yu, Y. Zhang, L. Schideman, T. L. Funk and Z. Wang, "Hydrothermal Liquefaction of Low Lipid Content Microalgae into Bio-Crude Oil," Transactions of the American Society of Agricultural and Biological Engineers, Vol. 54, No. 1, 2011, pp. 239-246.

[53] National Renewable Energy Laboratory, "Photovoltaic Solar Resource of the United States [graphic]," 2012. http://www.nrel.gov/gis/images/eere_pv/national_photov oltaic_2012-01.jpg

[54] K. Fitzsimmons, "Marketing of Tilapia in the USA," 2000. http://ag.arizona.edu/azaqua/tilapia/Thailand/paper.htm

[55] J. C. Kammerer, "Largest Rivers in the United States," United States Geological Survey Open-File Report 87242, United States Geological Survey, Reston, 1990.

[56] S. H. Wang, D. G. Huggins, F. deNoyelles, J. O. Meyer and J. T. Lennon, "Assessment of Clinton Lake and its Watershed," Kansas Biological Survey Report 96, Kansas Biological Survey, University of Kansas, Lawrence, 2000 . 